\title{
咽喉頭異常感症の無投薬治療
}

\author{
山際 幹和・坂倉 康夫
}

\section{Psychotherapy of Patients with Abnormal Sensation in the Throat}

\author{
Mikikazu Yamagiwa and Yasuo Sakakura \\ (Mie University)
}

We have treated 100 patients with abnormal sensation, such as a lump or choking, in the throat without using any medicine for 3 weeks. We classified the effectiveness of psychotherapy into 4 groups: markedly effective (the initial abnormal sensation was reduced by $80 \%$ or more), moderately effective (more than $50 \%$ but less than $80 \%$ ), slightly effective (more than 20\% but less than 50\%) and not effective (less than 20\%) at the end of 1, 2 and 3 weeks of treatment.

1) The average reduction of the initial sensation was $29 \%$ at 1 week, $35 \%$ at 2 weeks and $38 \%$ at 3 weeks. The marked and moderate effectiveness rates were, respectively, $9 \%$ and $27 \%$ at 1 week, $17 \%$ and $27 \%$ at 2 weeks, and $25 \%$ and $20 \%$ at 3 weeks.

2) The present psychotherapy seemed to be effective for the following patients : more than 50 years of age ; without any occupation ; with symptoms other than throat discomfort ; those who responded well to previous medication for throat discomfort ; not cancerphobic ; less than 6 months since onset ; complaining of discomfort higher than the hyoid bone; those with a choking sensation; not very neurotic by psychiatric tests.

The results indicate that psychotherapy for this condition is not very effective if total cure is the goal and that it should not be the first choice of treatment. On the other hand, these data obtained from psychotherapy can provide a good reference for determining the effectiveness of various drugs in the treatment of abnormal sensation in the throat as long as the same criteria are used for the classification of effectiveness.

Key words: abnormal sensation in the throat, therapy without medicine, evaluation of effectiveness of treatment

はじめに

咽喉頭異常感症は極めて心理的要因の関与し た病態であり，心理的治療がよく奏功するもの と予測される. 我々も, 以前にプラシーボ112) の投与や本症に無効と考兄られる処置 ${ }^{3}$ を行っ て，それらが少なからず効果を発揮することを
観察した.ただ，それらにより症状が完全に消 失し得るか否かの点に注目すると, 症状の消失 率は効果的と考えられる薬哓を投与した際注ど 高くないことも事実である4).

そこで, 今回は, 咽喉頭異常感症患者に対し て，まったく投薬することなく病態の説明や説 
得だけを行った場合， 1，2，3 週目には，全体 としてはどの程度の改善が得られるか, 項目別 にみてどのような場合に効果が高いか，の 2 点 を中心に検討した。

これらの点をあらかじめ把握しておくことは， 咽喉頭異常感症を効果的に治療するらえで極め て意義があると考える。

\section{対象ならびに方法}

1989 (平成元)年11月より 1991 (平成 3 ) 年 5 月 までの間に三重大学医学部附属病院あるいはそ の関連病院耳鼻咽喉科を咽喉頭異常感を主訴と して受診し, 著者の一人が咽喉頭異常感症と診 断し，無投薬で治療した一連の患者100例を解 析対象とした。

独自の咽喉頭異常感症患者調査表に基づいた 詳細な問診，一定の基準に従った入念な耳鼻咽 喉局所の診察，悪性腫瘍の否定を目的とした食 道造影撮影, コーネル・メディカル・インデッ クス (CMI) 健康調査表5) とモーズレイ性格検査 $\left.(\mathrm{MPI})^{6}\right)$ を用いた心理・性格検査および各種血 液検査を必須として行ったらえで治療を開始し た。

患者に対する必須の説明は以下のようにした。 無投薬治療開始前には，原則的に，悪性腫瘍の 可能性は極めて薄く, 症状が局所の炎症に起因 している可能性が高いため，無投薬で様子をみ ても改善する場合があることを説明した。1 1 あ るいは 2 週目には，病状を聴き，各検査結果を 説明し，病状の改善している例には再燃の可能 性は薄いことを，また改善していない例にはま だ改善の余地があることを説明した。 3 週目で は, 改善例には以後の注意点を説明し, 治療を 打ち切った. 非改善例に対しては治療方法を变 更した.

\section{治療効果の判定}

咽喉頭異常感の頻度はともかくとして，その 程度を客観的に評価することは不可能に近いこ とから, 自覚症状を検討して治療効果を判定し た，その方法は，個々の患者が治療前に有した 咽喉頭異常感の自覚的な強さ (程度十頻度) は評
価せず，一律にそれを10点とし，無症状を 0 点 とした場合，治療開始後 1,2 および 3 週目に はそれが何点になったかを患者自身に採点させ る方法である。

そして，治療後の点数が $8 \sim 10$ 点を無効, 6 $\sim 7$ 点をやや有効, $3 \sim 5$ 点を有効, $\quad 0 \sim 2$ 点 を著効と評価した。また，5点以下 (症状が 50 $\%$ 以上改善)を広義の有効と判定し，その有効 率を以下の表中に提示した。

これとは別に，投与開始前の咽喉頭異常感の 頻度を, 常に感じる, 時々感じる, まれに感じ る，全く感じない，の 4 段階に分類し，それが 治療開始後 1,2 および 3 週目にはどら推移し たかも参考として検討した.

\section{治療成績}

1. 治療開始後の咽喉頭異常感スコアーの 推移

図 1 は，全100例が自己採点した治療開始後 の咽喉頭異常感スュアーの推移を示す. 1 週目 では，4\%で咽喉頭異常感が完全に消失 ( 0 点) し，有効以上と評価された例は $36 \%$ に達した。 しかしながら，41\%ではその時点で全く効果が 得られていなかった。すなわち，10点のままで あった。 2 週目では， 1 週目に比べ著効率は上 昇したが，まったく無効である例の比率 $(38 \%)$ と完全に異常感が消失した例の比率 (4\%)は殆 ぞ変動しなかった。 3 週目では，2 週目より更 に著効率が増加し, 症状が消失した例の比率も $8 \%$ に上昇した，他方，無効あるいはやや有効 と評価された例の比率は変動せず，とくに，ま ったく効果が得られない例の比率は高いままで 3 週間維持された.

この得点の平均と標準偏差の推移は図 2 のよ らになった，前述のように，治療開始前は 10 点

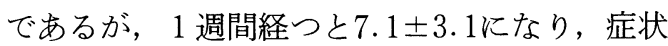
がかなり軽減することが窺えた。 2 と 3 週目の それは $6.5 \pm 3.4$ 抢よび $6.2 \pm 3.8$ であり, 減少傾 向は軽微で注ぼプラトーになった。

2. 咽喉頭異常感を感じる頻度の推移

図 3 に示したように，治療開始前には，咽喉 
頭異常感を常に感じていた例(以下「常に」)が 69\%で，時々感じていた例(以下「時々」)が31 \%であった。それが 1 週目では「常に」が47\% に激減し，代わって，全く感じない例（以下「な し」)やまれに感じるくらい(以下「まれ」)にな った例が出現した。 2 週目では「時々」が減少 し，「まれ」が増加したが，他は変化しなかっ た. 3 週目の成績は 2 週目のそれとほぼ同様で あった．傾向としては，図 2 亿示した咽喉頭異 常感スコアーの平均と標準偏差の推移に近似し た形で 2 週目で殆どプラトーになっている.
3. 項目別にみた治療成績

1) 性別（表 1 )にみると，女性例が多く，そ の有効率(広義) は男性例のそれに比べ僅かに高 かった。

2 ) 年㱓別(表 1 ) そみた場合, 50歳以上の例 の成績がそれ未満の例の成績と比べ良好である ことが目立ったが，有意ではなかった。ただし， 患者を50歳以上と50歳未満の 2 群に大別しU検 定すると， 3 週目の前者の成績は後者のそれに 比べ有意 $(\mathrm{p}<0.05)$ に良好であった。

3 ) 職業(表 1 )を有した例は男性例が多かっ

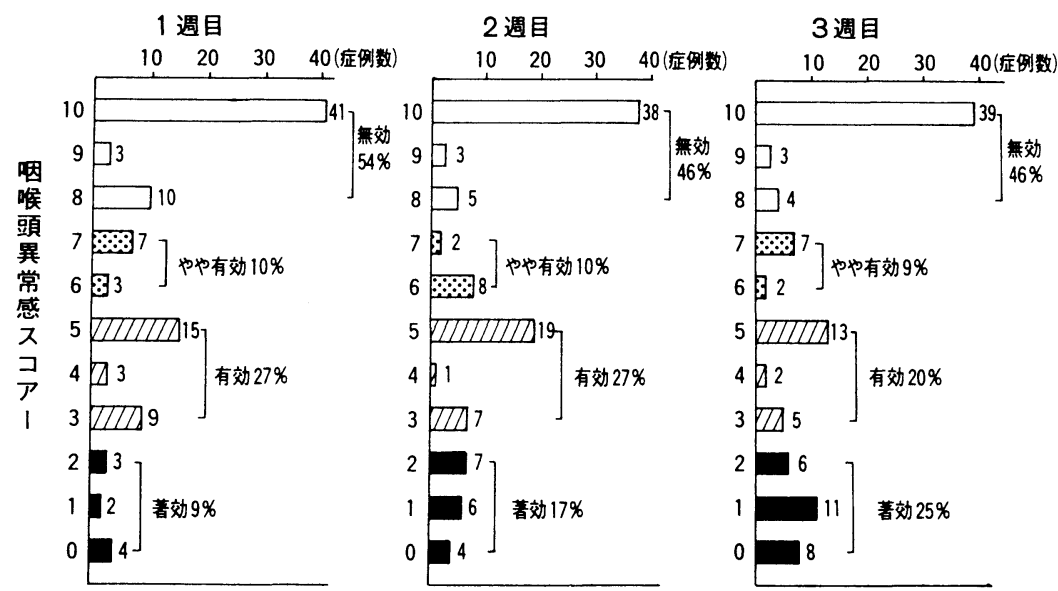

図 1 咽喉頭異常感症100例(男性34例, 女性66例)に対する無投薬治療の効果 治療開始前の異常感の強さを一律「10」とし, 異常感のない状態を「0」と した場合の各週に拈けるスコアーの分布を示す。

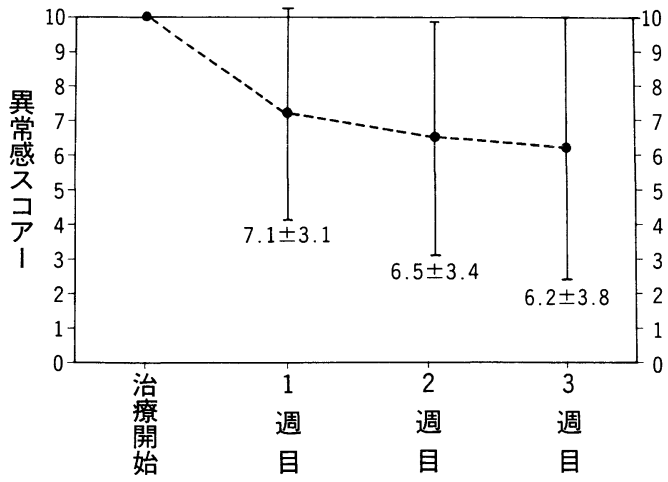

図 2 咽喉頭異常感スコアー(平均士標準偏差)の 推移 （無投薬治療 100例）

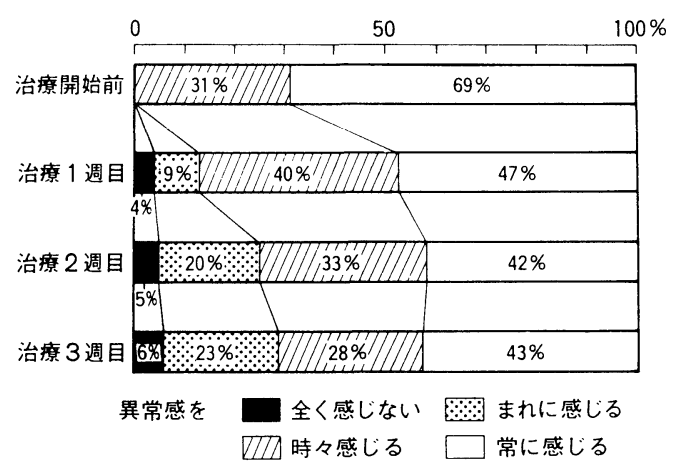

図 3 咽喉頭異常感を感じる頻度の推移 (無投薬治療 100例) 
たが，それらの例の成績は職業を持たない例の それに比べ不良であり, 特に, 3 週目の両者の 成績の間には有意差 $(\mathrm{p}<0.05)$ があった。

4 ) 䝟煙歴 (表 1 )の無い例は女性例を多く含 んでいたが，その有無により成績に差が生じる ことはなかった。

5 ）飲酒歴(表 1 )を有した例の多くは男性例 であったが，その有無による成績の差はなかっ た。
6 ）随伴症（表 1 )の無い例は，有る例に比べ 幾分良好な成績を示したが，有意ではなかった。

7 ）合併症(表 1 )を有した例はとれを有さな かった例より良好な成績を呈し，特に 1 週目で 両者の成績の間に有意差 $(\mathrm{p}<0.05)$ が認められ た。

8 ）前医により薬物治療(表 1)が行われた例, すなわち，今回の無投薬治療を行う前に，既に 何らかの薬剤による治療が行われていた例が34

表 1 症例の背景因子と治療成績

（無投薬治療 100例）

\begin{tabular}{|c|c|c|c|c|c|c|c|}
\hline & & & \multirow{2}{*}{ 例数 } & \multicolumn{3}{|c|}{ 有 効 例 $(\%)$} & \multirow{2}{*}{ 検 定 結 果 } \\
\hline & & & & 1 週目 & 2 週目 & 3 週目 & \\
\hline & 全 & 症＼cjkstart例 & 100 & $36(36)$ & $44 \quad(44)$ & $45 \quad(45)$ & \\
\hline \multirow{2}{*}{ 性 } & \multicolumn{2}{|r|}{ 男 } & 34 & $12(35)$ & $13(38)$ & 14 (41) & \multirow{2}{*}{ 有意差なし } \\
\hline & \multicolumn{2}{|r|}{ 女 } & 66 & $24 \quad(36)$ & $31 \quad(47)$ & $31 \quad(47)$ & \\
\hline \multirow{5}{*}{$\begin{array}{l}\text { 年 } \\
\text { 齢 } \\
\text { 噦 } \\
\text { 式 }\end{array}$} & \multicolumn{2}{|r|}{20} & 6 & $1(17)$ & $1(17)$ & $2(33)$ & \multirow{5}{*}{ 有意差なし } \\
\hline & \multicolumn{2}{|r|}{30} & 11 & $4(36)$ & $5(45)$ & $3(27)$ & \\
\hline & \multicolumn{2}{|r|}{40} & 28 & $7(25)$ & $10(36)$ & $10(36)$ & \\
\hline & \multicolumn{2}{|r|}{50} & 31 & $15(48)$ & $16(52)$ & $19(61)$ & \\
\hline & \multicolumn{2}{|r|}{$60 \leqq$} & 24 & $9(38)$ & $12(50)$ & $11(46)$ & \\
\hline \multirow{2}{*}{$\begin{array}{l}\text { 職 } \\
\text { 業 }\end{array}$} & \multicolumn{2}{|r|}{ あり } & 58 & $19(33)$ & $21 \quad(36)$ & $21 \quad(36)$ & \multirow{2}{*}{$\begin{array}{l}3 \text { 週目のありとなしの間に有意 } \\
\text { 差 }(\mathrm{U} \text { 検定で } \mathrm{p}<0.05) \text { あり }\end{array}$} \\
\hline & & なし & 42 & $17(40)$ & $23(55)$ & $24 \quad(57)$ & \\
\hline \multirow{2}{*}{$\begin{array}{l}\text { 契 } \\
\text { 堙 } \\
\text { 歴 }\end{array}$} & \multicolumn{2}{|r|}{ あり } & 34 & $13(38)$ & $13(38)$ & 14 (41) & \multirow{2}{*}{ 有意差なし } \\
\hline & & なし & 66 & 23 (35) & $31(47)$ & $31 \quad(47)$ & \\
\hline \multirow{2}{*}{$\begin{array}{l}\text { 飲 } \\
\text { 酒 } \\
\text { 歴 }\end{array}$} & \multicolumn{2}{|r|}{ あり } & 20 & $7(35)$ & $8(40)$ & $9(45)$ & \multirow{2}{*}{ 有意差なし } \\
\hline & & なし & 80 & $29(36)$ & $36(45)$ & $36(45)$ & \\
\hline \multirow{2}{*}{$\begin{array}{l}\text { 随 } \\
\text { 伴 } \\
\text { 症 }\end{array}$} & \multicolumn{2}{|r|}{ あり } & 52 & 17 (33) & $22(42)$ & $21 \quad(40)$ & \multirow{2}{*}{ 有意差なし } \\
\hline & & なし & 48 & $19(40)$ & $22(46)$ & $24(50)$ & \\
\hline \multirow{2}{*}{$\begin{array}{l}\text { 合 } \\
\text { 併 } \\
\text { 症 }\end{array}$} & \multicolumn{2}{|r|}{ あり } & 47 & $23(49)$ & $24(51)$ & $23(49)$ & \multirow{2}{*}{$\begin{array}{l}1 \text { 週目のありとなしの間に有意 } \\
\text { 差(U検定で } \mathrm{p}<0.05) \text { あり }\end{array}$} \\
\hline & \multicolumn{2}{|r|}{ なし } & 53 & $13(25)$ & $20(38)$ & $22(42)$ & \\
\hline \multirow{4}{*}{$\begin{array}{l}\text { 前 } \\
\text { 治 } \\
\text { 療 }\end{array}$} & \multirow{3}{*}{$\begin{array}{l}\text { あ } \\
\text { り }\end{array}$} & 前治療は有効 & 10 & 6(60) & $7(70)$ & $6(60)$ & \multirow{4}{*}{ 有意差なし } \\
\hline & & 前治療は無効 & 24 & $6(25)$ & $8(33)$ & $7(29)$ & \\
\hline & & 合計 & 34 & $12(35)$ & $15(44)$ & $13(38)$ & \\
\hline & & なし & 66 & $24 \quad(36)$ & $29(44)$ & $32(48)$ & \\
\hline
\end{tabular}


例あり，未治療例は66例であった，両者の成績 の間には大差はなかったが，既治療例のなかで 前治療が有効であった例に対して今回の無投薬 治療が奏功した点が目立った。

9 ) 肥満度 (表 2 )をみると，過体重と評価さ れた例の成績が幾分不良であったが，有意では なかった。

10）自己評価した性格（表 3 ）をみると，56\% の例が神経質であると評価している。そして， 重複はあるが，几帳面あるいは苦労症と自己評
価した例がそれぞれ約 $30 \%$ あった。それらの成 績と楽天的と答えた例の成績の間には殆ど差が なかった。

11）咽喉頭異常感が癌の症状ではないかと考 光，咽喉頭部の癌に対する不安(表 3 )を持って 受診した例が $72 \%$ 占めていた。それらの例の 成績は不良で，その不安の無い例の成績との間 には 1 週目で有意差 $(\mathrm{p}<0.05)$ があった。 2 週 目でもかなりの差があり， 3 週目ではかなり改 善をみたものの，不安の無い例のそれよりはま

表 2 肥満度と治療成績

（無投薬治療 100 例）

\begin{tabular}{|c|c|c|c|c|c|c|}
\hline & & \multirow{2}{*}{ 例数 } & \multicolumn{3}{|c|}{ 有 効 例 $(\%)$} & \multirow{2}{*}{ 検定結果 } \\
\hline & & & 1 週目 & 2 週目 & 3 週目 & \\
\hline \multirow{2}{*}{ 肥 } & 肥満 $(+20 \leqq x)$ & 17 & $7(41)$ & $9(53)$ & $8(47)$ & \multirow{5}{*}{ 有意差なし } \\
\hline & 過体重 $(+10 \leqq x<+20)$ & 19 & $6(32)$ & $5(26)$ & $6(32)$ & \\
\hline \multirow{3}{*}{$\begin{array}{l}\text { 度 } \\
\stackrel{0}{0}\end{array}$} & 普通 $(-10<x<+10)$ & 57 & $19(33)$ & $25(44)$ & $27(47)$ & \\
\hline & るいそう $(-20<x \leqq-10)$ & 6 & $3(50)$ & $4(67)$ & $3(50)$ & \\
\hline & 甚だるいそら $(x \leqq-20)$ & 1 & $1(100)$ & $1(100)$ & $1(100)$ & \\
\hline
\end{tabular}

※〔身長 $(\mathrm{cm})-100] \times 0.9$ を標準体重 $(\mathrm{kg})$ とし，それで実際の体重 $(\mathrm{kg})$ を割り， 過少を\%表示した。

表 3 自己評価した性格や癌に対する不安の有無別にみた治療成績

（無投薬治療 100例）

\begin{tabular}{|c|c|c|c|c|c|c|}
\hline & & \multirow{2}{*}{ 例数 } & \multicolumn{3}{|c|}{ 有 効 例 $(\%)$} & \multirow{2}{*}{ 検 定 結 果 } \\
\hline & & & 1 週目 & 2 週目 & 3 週目 & \\
\hline \multirow{6}{*}{$\begin{array}{l}\text { 自 } \\
\text { 評重 } \\
\text { 価複 } \\
\text { 㐫 } \\
\text { たり } \\
\text { 性 } \\
\text { 格 }\end{array}$} & 楽天的 & 21 & $10(48)$ & $9(43)$ & $9(43)$ & \multirow{6}{*}{ 有意差なし } \\
\hline & 神経質 & 56 & $17(30)$ & $23(41)$ & $23(41)$ & \\
\hline & 几帳面 & 30 & $9(30)$ & $13(43)$ & $14(47)$ & \\
\hline & 苦労性 & 29 & $12(41)$ & $14(48)$ & $15(52)$ & \\
\hline & 感情不安定 & 14 & $5(36)$ & 4(29) & $7(50)$ & \\
\hline & 上記のどれでもない & 4 & $2(50)$ & $2(50)$ & $2(50)$ & \\
\hline \multirow{2}{*}{$\begin{array}{l}\text { 癌 } \\
\text { に不 } \\
\text { 対 } \\
\text { す安 } \\
\text { る }\end{array}$} & あり & 72 & $21 \quad(29)$ & $28(39)$ & $30(42)$ & \multirow{2}{*}{$\begin{array}{l}1 \text { 週目のありとなしの間に有 } \\
\text { 意差 }(\mathrm{U} \text { 検定で } \mathrm{p}<0.05) \text { あり }\end{array}$} \\
\hline & なし & 28 & $15(54)$ & $16(57)$ & $15(54)$ & \\
\hline
\end{tabular}


表 4 発症より治療開始までの期間と治療成績

（無投薬治療 100 例）

\begin{tabular}{|c|c|c|c|c|c|c|}
\hline & & \multirow{2}{*}{ 例数 } & \multicolumn{3}{|c|}{ 有 効 例 $(\%)$} & \multirow{2}{*}{ 検定結果 } \\
\hline & & & 1 週目 & 2 週目 & 3 週目 & \\
\hline \multirow{4}{*}{$\begin{array}{l}\text { 登䇂 } \\
\text { 占の } \\
\text { 期 } \\
\text { 浩間 } \\
\text { 尞月 } \\
\text { 始 }\end{array}$} & $x \leqq 1$ & 34 & $13(38)$ & $17(50)$ & $17(50)$ & \multirow{4}{*}{ 有意差なし } \\
\hline & $1<x \leqq 6$ & 31 & $13(42)$ & $15(48)$ & $18(58)$ & \\
\hline & $6<x \leqq 12$ & 4 & $0(0)$ & $0(0)$ & $0(0)$ & \\
\hline & $12<x$ & 31 & $10(32)$ & $12(39)$ & $10(32)$ & \\
\hline
\end{tabular}

表 5 異常感を訴える部位およびその性状と治療成績

（無投薬治療 100例）

\begin{tabular}{|c|c|c|c|c|c|c|c|}
\hline & & & \multirow{2}{*}{ 例数 } & \multicolumn{3}{|c|}{ 有 効 例 $(\%)$} & \multirow{2}{*}{ 検 定 結 果 } \\
\hline & & & & 1 週目 & 2 週目 & 3 週目 & \\
\hline \multirow{5}{*}{ 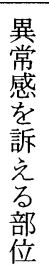 } & \multicolumn{2}{|l|}{ 舌骨以上 } & 19 & $10(53)$ & $11(58)$ & $11(58)$ & \multirow{3}{*}{$\begin{array}{l}2 \text { 週目の成績に } \\
\text { 有意差 ( H検定で } \\
\mathrm{p}<0.05) \text { あり }\end{array}$} \\
\hline & \multicolumn{2}{|l|}{ 舌骨輪状軟骨間 } & 28 & 11 (39) & $16 \quad(57)$ & $14(50)$ & \\
\hline & \multicolumn{2}{|l|}{ 輪状軟骨以下 } & 53 & $15(28)$ & $17(32)$ & $20(38)$ & \\
\hline & \multicolumn{2}{|l|}{ 正中 } & 67 & $26(39)$ & $29(43)$ & $31(46)$ & \multirow{2}{*}{ 有意差なし } \\
\hline & \multicolumn{2}{|l|}{ 側方 } & 33 & $10(30)$ & $15(45)$ & $14(42)$ & \\
\hline & \multicolumn{2}{|c|}{$\begin{array}{l}\text { A. 内腔に空間を占拠する物理 } \\
\text { 的変化がある感じ } \\
\text { (何かつまっている, 等) }\end{array}$} & 72 & $22(31)$ & $28 \quad(39)$ & $29(40)$ & \multirow{3}{*}{ 有意差なし } \\
\hline $\begin{array}{l}\text { 異 } \\
\text { 常 }\end{array}$ & \multicolumn{2}{|c|}{ 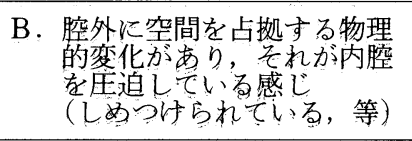 } & 10 & $7(70)$ & $7(70)$ & $7(70)$ & \\
\hline 感 & \multicolumn{2}{|c|}{$\begin{array}{l}\text { C. 卡記以外の異常感 } \\
\text { (はしか心，等) }\end{array}$} & 18 & $7(39)$ & $9(50)$ & $9(50)$ & \\
\hline \multirow[t]{2}{*}{ の } & \multirow{2}{*}{$\begin{array}{l}\text { 空嚥下による出現, } \\
\text { 増強 }\end{array}$} & あり & 40 & $14(35)$ & $17(43)$ & $17(43)$ & \multirow{2}{*}{ 有意差なし } \\
\hline & & なし & 60 & $22(37)$ & $27(45)$ & $28(47)$ & \\
\hline \multirow{4}{*}{ 状 } & \multirow{4}{*}{$\begin{array}{l}4 \% \text { \%シカイン® } \\
\text { 表面麻酔の異常感 } \\
\text { に対する效果* } \\
\text { (70例で検討) }\end{array}$} & 著効 & 52 & $17(33)$ & $24(46)$ & $23(44)$ & \multirow{4}{*}{ 有意差なし } \\
\hline & & 有効 & 6 & $2(33)$ & $2(33)$ & $2(33)$ & \\
\hline & & やや有効 & 4 & $0(0)$ & $0(0)$ & $0(0)$ & \\
\hline & & 無効 & 8 & $2(25)$ & $5(63)$ & $4(50)$ & \\
\hline
\end{tabular}

${ }^{*}$ 麻酔により異常感が $80 \%$ 以上軽減 : 著効 $50 \%$ 以上 $80 \%$ 未満軽減：有効 $20 \%$ 以上 $50 \%$ 末満軽減 : やや有効 $20 \%$ 未満軽減：無効 
だ相当劣っていた.

12）発症より治療開始までの期間(表 4)をみ ると，大多数 (65\%)の患者が症状発現より 6 力 月以内に治療を開始し，その成績はかなり良好 であった。 それに対して，6 カ月を越えてから 治療を開始した例の成績は不良であり，患者を それらの 2 群に大別しU検定を行らと，3 週目 の両者の成績の間には有意差 $(\mathrm{p}<0.05)$ があっ た。

13）異常感を訴える部位(表 5 ) は, 輪状軟骨 以下で，正中部が多かったが，それらの例の成 績は不良であった。他方，それよりも上位，特 に舌骨以上飞訴えた例は $19 \%$ であったが，今回 の無投薬治療に良く反応した。そして，H検定 で部位と成績の間に関連性があることが示され た。

訴える部位が正中か側方かにより成績に差が 生じることはなかった。

14）異常感の性状（表 5 )を又ると，気道ある いは消化管の内腔に空間を占拠する何かがある

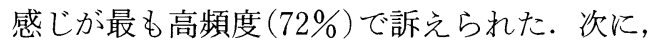
咽喉部がいがらっぽい感じ(当地方の言葉で, はしかい感じ)を訴えた例が多かった(18\%)が，
両者の成績の間に大きい差はなかった。気道あ るいは消化管の内腔を外側より圧迫される感じ を訴光た例は10\%で，その成績はかなり良好で あった。

空嚥下により咽喉頭異常感が増強したり出現 すると答えた例が $40 \%$ ，そらでないと答えた例 が60\%であったが，その有無による成績の違い は明白ではなかった。

$4 \%$ \%ロカイン®(リドカイン)を用いて， 中咽頭粘膜を中心に軽く表面麻酔すると7), 効 果を検討し得た70例中52例 (74\%) で咽喉頭異常 感は著しく軽減あるいは消失した。それらの例 や表面麻酔で殆ど異常感が変化しなかった 8 例 (11\%)の成績は良好であったが，残りの適度に 表面麻酔効果の出現した10例(14\%)の成績は不 良であった。ただし，推計学的には有意ではな かった.

15）習慣的に咽頭痛をきたす（表 6 ）と答えた 例は $42 \%$ あり，それらの成績はそらでない例の 成績と比べ若干不良であったが，両者の差は有 意ではなかった。

16）咽頭炎所見（表 6)が明らかにあった例は 23\%，逆に，それが無いといってょい例は28\%

表 6 咽喉頭部の炎症所見と治療成績

（無投薬治療 100例）

\begin{tabular}{|c|c|c|c|c|c|c|}
\hline & & \multirow{2}{*}{ 例数 } & \multicolumn{3}{|c|}{ 有 効 例 $(\%)$} & \multirow{2}{*}{ 検定結果 } \\
\hline & & & 1 週目 & 2 週目 & 3 週目 & \\
\hline \multirow{2}{*}{$\begin{array}{l}\text { 習 } \\
\text { 慣 } \\
\text { 姓 } \\
\text { 頭 } \\
\text { 痛 }\end{array}$} & あり & 42 & $13(31)$ & $16(38)$ & $15(36)$ & \multirow{2}{*}{ 有意差なし } \\
\hline & なし & 58 & $23(40)$ & 28 (48) & $30(52)$ & \\
\hline \multirow{3}{*}{$\begin{array}{l}\text { 咽 } \\
\text { 頭 } \\
\text { 炎 } \\
\text { 所 } \\
\text { 見 }\end{array}$} & 無いといってよい & 28 & $11(39)$ & $13(46)$ & $13(46)$ & \multirow{3}{*}{ 有意差なし } \\
\hline & $\begin{array}{l}\text { 無いとはいえないが, } \\
\text { 範囲を越えなてい生理的 }\end{array}$ & 49 & $17(35)$ & $24 \quad(49)$ & $23(47)$ & \\
\hline & 明らかにある & 23 & 8(35) & $7(30)$ & $9(39)$ & \\
\hline
\end{tabular}


表 7 CMI 健康調查結果と治療成績

（無投薬治療 100 例）

\begin{tabular}{|c|c|c|c|c|c|c|}
\hline & & \multirow{2}{*}{ 例数 } & \multicolumn{3}{|c|}{ 有 効 例 $(\%)$} & \multirow{2}{*}{ 検定結果 } \\
\hline & & & 1 週目 & 2 週目 & 3 週目 & \\
\hline \multirow{4}{*}{$\begin{array}{l}\text { 深 } \\
\text { 町領 } \\
\text { 淢 } \\
\text { 法 }\end{array}$} & I（心理的正常） & 39 & $12(31)$ & $15(38)$ & $16(41)$ & \multirow{4}{*}{ 有意差なし } \\
\hline & II（心理的正常の可能性が強い） & 26 & $10(38)$ & $13(50)$ & $14(54)$ & \\
\hline & III（神経症である可能性が強い） & 27 & $12(44)$ & $14(52)$ & $12(44)$ & \\
\hline & N（神経症と判定できる） & 8 & $2(25)$ & $2(25)$ & $3(38)$ & \\
\hline \multirow{4}{*}{$\begin{array}{l}\text { 阿 } \\
\text { 部 } \\
\text { 㵏型 } \\
\text { 法 }\end{array}$} & I （正常） & 58 & $20(34)$ & $24(41)$ & $27(47)$ & \multirow{4}{*}{ 有意差なし } \\
\hline & II（自律神経失調症） & 10 & $3(30)$ & $5(50)$ & $5(50)$ & \\
\hline & III（神経症） & 12 & $6(50)$ & $6(50)$ & $5(42)$ & \\
\hline & N（心身症） & 20 & $7(35)$ & $9(45)$ & $8(40)$ & \\
\hline \multirow{2}{*}{$\begin{array}{l}\text { 抑傾 } \\
5 \\
\text { つ向 }\end{array}$} & あり & 21 & $10(48)$ & $10(48)$ & $9(43)$ & \multirow{2}{*}{ 有意差なし } \\
\hline & なし & 79 & $26(33)$ & $34(43)$ & $36(46)$ & \\
\hline
\end{tabular}

表 8 モーズレイ性格検査 (MPI) 結果と治療成績

（無投薬治療 100 例）

\begin{tabular}{|c|c|c|c|c|c|c|}
\hline & & \multirow{2}{*}{ 例数 } & \multicolumn{3}{|c|}{ 有 効 例（\%） } & \multirow{2}{*}{ 検定結果 } \\
\hline & & & 1 週目 & 2 週目 & 3 週目 & \\
\hline \multirow{5}{*}{$\begin{array}{l}\text { ME } \\
\text { P } \\
\text { I 度 } \\
\text { 得 } \\
\text { 点 }\end{array}$} & $0 \sim 9$ (非常に内向的) & 8 & $3(38)$ & $4(50)$ & $3(38)$ & \multirow{5}{*}{ 有意差なし } \\
\hline & 10 20（やや内向的） & 36 & $16(44)$ & $21(58)$ & $21(58)$ & \\
\hline & 21～31（普通） & 27 & $8(30)$ & $11(41)$ & $12(44)$ & \\
\hline & 32 41（やや外向的） & 24 & $9(38)$ & $8(33)$ & $9(38)$ & \\
\hline & 42～48（非常に外向的） & 5 & $0(0)$ & $0(0)$ & $0(0)$ & \\
\hline \multirow{5}{*}{$\begin{array}{l}\text { MN } \\
\text { P } \\
\text { I 度 } \\
\text { 得 } \\
\text { 点 }\end{array}$} & 0〜 8（神経症的傾向殆どなし） & 37 & $13(35)$ & $15(41)$ & $16(43)$ & \multirow{5}{*}{ 有意差なし } \\
\hline & 9～18（神経症的傾向は低い） & 27 & $12(44)$ & $14(52)$ & $14(52)$ & \\
\hline & 19～28（普通） & 26 & $9(35)$ & $13(50)$ & $12(46)$ & \\
\hline & 29～38（神経症的傾向がある） & 5 & $1(20)$ & $1(20)$ & $2(40)$ & \\
\hline & 39〜48（神経症的傾向が非常に強い） & 5 & $1(20)$ & $1(20)$ & $1(20)$ & \\
\hline \multirow{3}{*}{$\begin{array}{l}\text { ML } \\
\text { P 度 } \\
\text { I 得 } \\
\text { 点 }\end{array}$} & 0〜 6（低得点カテゴリー） & 2 & $1(50)$ & $1(50)$ & $1(50)$ & \multirow{3}{*}{ 有意差なし } \\
\hline & 7〜20（中得点カテゴリー） & 52 & $17(33)$ & $19(37)$ & $20(38)$ & \\
\hline & 21〜40（高得点カテゴリー） & 46 & $18(39)$ & $24(52)$ & $24(52)$ & \\
\hline \multirow{2}{*}{$\begin{array}{l}\text { 不 回 } \\
\text { 明? 䈏 } \\
\text { 数 }\end{array}$} & 0１9（許容範囲内） & 89 & $32(36)$ & $39(44)$ & $41(46)$ & \multirow{2}{*}{ 有意差なし } \\
\hline & $20 \sim \quad($ 多い) & 11 & $4(36)$ & $5(45)$ & $4(36)$ & \\
\hline
\end{tabular}


であり，残りの $49 \%$ では無いとはいえないが， あったとしても生理的範囲を越えない程度であ った．咽頭の炎症所見が明らかに存在した例の 成績は幾分不良であったが，有意ではなかった。

17） CMI 健康調査結果を深町法5), 阿部法変 法8）を用いて評価し，更に，そこから抑らつ傾 向を探ってみた(表 7 ).

深町法5)では，神経症と判定できるとされる $\mathrm{IV}$ 領域例の成績が最も不良で，次に，心理的正 常と評価された I 領域例の成績が不良であった。 しかしながら，それは有意ではなかった。

阿部法変法8)では，自律神経失調状態に神経 症的傾向の加わった心身症型 $(N$ 型) の成績がや や不良であったが，分類された型と成績の間に は関連性はなかった。

抑らつ傾向の評価は容易ではないが，CMI 健康調查表の抑らつ $(\mathrm{N})$ の七ッョョンの質問 6

\section{I) 口蓋扁桃慢性炎症所見 (100例)}

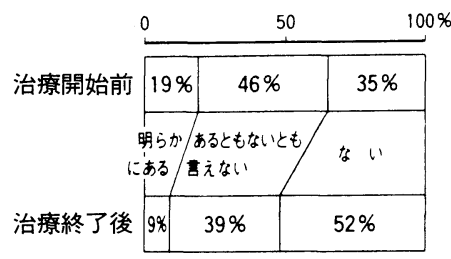

II ) 口蓋扁桃発赤 (100例、200側)

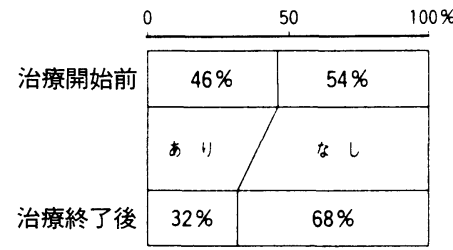

III) 口蓋扁桃突出肥大 (100例、200側、

$$
\text { マッケンジー分類) }
$$

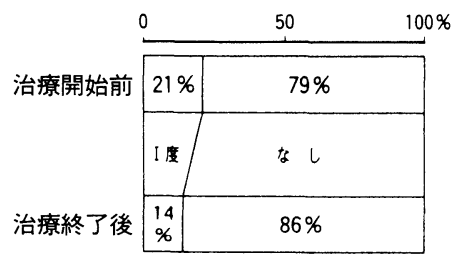

問中 1 問以上に「はい」と回答した例を「抑う つ傾向あり」とすると帛，21\%は抑らつ傾向あ りと評価された。それらの成績はそうでない例 の成績と比べ差がなかった。

18）モーズレイ性格検査 (MPI) 結果(表 8) をMPI 研究会により提示された方法6)に従っ て評価し, 以下の点を検討した.

外向性一内向性 $(\mathrm{E})$ 尺度得点は, 高い汪ど外 向的であるとされている.「非常に外向的」あ るいは「非常に内向的」と評価された例は少な かった。「やや内向的」あるいは「普通」と評 価された例の成績が良好であったが，有意では なかった。

神経症的傾向 $(\mathrm{N})$ 尺度得点は，高い汪ど神経 症的傾向が強いとされている。CMI 深町法に よる評価結果5) と同様に，ここでも神経症傾向 が窥われる例の成績が不良であった。しかしな

N) 咽頭側索発赤 (100例、200側)

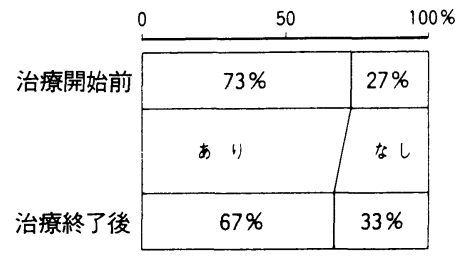

V) 咽頭後壁発赤 (100例)

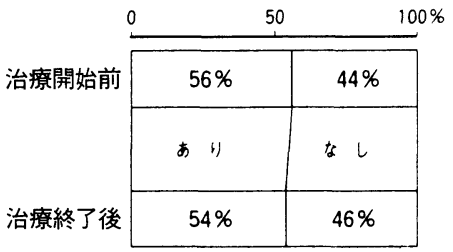

V) 舌扁桃肥大 (100例)

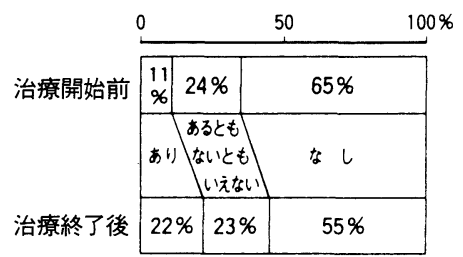

図 4 咽喉頭異常感症患者の咽頭所見の推移 
がら, 推計学的には有意ではなかった。

虚偽発見 $(\mathrm{L})$ 尺度得点は，自分をよく見せよ うとして，虚偽の回答をすると高くなる。この 得点が高い例の成績は良好であったが，有意で はなかった。

不明 (?) 回答数が多い(20以上) と回答が歪ん だものになるとされている。ここでは，それが 多い例とそらでない例との間で成績の差はなか った。

19）咽頭局所の炎症所見（図 4 )が 3 週間でど のよらに推移するかを検討したところ，概して リンパ組織の発赤や腫脹は僅かずつではあるが 軽快するようである。しかしながら，客観的な 評価が困難であり断言は避けたい。

\section{考察}

咽喉頭異常感を訴えて受診する患者の中には, 様々の内科的あるいは耳鼻咽喉科的検査を受け たにもかかわらず異常所見が見いだされなかっ たために，検査結果の説明だけを受け，薬物を 用いた治療を全く受けたことのない例が少なか らず含まれている。そのような患者の中には， 「異常がないのに症状が続く」ことに納得がで きず再受診したり，あるいは，次々と医師をか えて精査治療を求める患者も少なくない。それ らの患者に対しては，一時的にせよ症状を取り 除いてやり, 最も恐れている癌に対する不安を 和らげてやることが極めて重要である.

その一方で, 病状の簡単な説明だけで十分納 得し, 以降極めて安定した状態が得られる患者 が存在することも事実である.

このような 2 群の患者を何らかの方法で治療 早期に選別できれば，ある意味で無䭾の少ない 医療が可能になる．今回の検討の狙いのひとつ はそこにある。

今回の検討結果から，3 週間の無投薬観察期 間内に全く症状が改善しなかった例が39\%あり， 55\%の例が決して満足できる状態に至らなかっ たことは投薬治療の重要性を強く示唆するもの である，その反面，著効を呈した例が $25 \%$ に達 し，完全に症状が消失した例も8\%認められた
点は, 症例によっては投薬治療を必ずしも必要 としないことを意味している。

それでは，どのような患者が無投薬治療に対 してょく反応するか, 言い替えれば, 病状の説 明だけで治瘉する可能性が高い患者像を今回の 検討成績より描いてみると，以下のょうになる。

1. 年齢は50歳以上で, 職業を持たず, 高血 圧症などの合併症を有している.

2. 咽喉頭異常感に対して過去に薬物を用い た治療を受けたことがあり，しかも，それが効 果的であった.

3. 自身の咽喉頭異常感を癌の症状とは考兄 てなく, 異常感は発症後 6 カ月以内で, それを 感じる部位は輪状軟骨よりも高い位置にある。 異常感の性質としては, 気道あるいは消化管を 何かがしめつけてくる感じである.

4. コーネル・メディカル・インデックス健 康調査やモーズレイ性格検査で著しい神経症的 傾向がない.

これらの条件のかなりの部分が揃っていれば, 試みに無投薬治療を行ってみる価値があるかも 知れない.

今回の無投薬治療と偽薬を用いた治療を同列 に扱っていいか否かの問題はあるが，心理的効 果の点では共通する部分があると考学られる. 以前我々は偽薬を用いて咽喉頭異常感症患者を 治療し, 偽薬が奏功した患者の特徵を報告し た1)2).それを今回の無投薬治療が奏功した患 者の特徵と対比させると, 両者はかなりの点で 一致する.すなわち, 偽薬にも無投薬治療にも 反応した患者像は以下のよらである。

1) 高㱓で職業を持たず，楽天的である.

2 ) 発症 6 力月以内である.

3 ）心理性格テストで神経症的傾向が低く, やや外向的と評価されている.

強調したいことは，あくまでも，ここに記述 した患者像は無投薬治療が奏功したひとにぎり の患者のそれであり, 先に述べたよらに, 全体 の比率から言えば，咽喉頭異常感を訴えて受診 する患者の多くて $25 \%$ である．低く見積れば10 
\%に満たない，その点を考えると，咽喉頭異常 感を訴えて受診した患者で，これらの条件のい くつかが揃っていたからといって，その患者に 対して無投薬治療は第一選択とはならないと考 える、全部の特徵を備えていても偽薬や無投薬 治療で完治する可能性はさ注ど高くないと考え る. したがって, 咽喉頭異常感症患者の治療に 打ける第一選択は発症原因を想定したらえでの 薬物を用いた治療であり，それを最初から行い 症状の除去に努め, 同時に, 円滑な患者医師関 係の確立を目指すことが極めて合理的な方法で あるといえる。

今回の検討のもら一つの狙いは，薬物を用い て咽喉頭異常感症の治療を行った際に, 真の薬 物の効果はどの程度あるのかを評価するための 資料を得ることにあった。つまり，薬物治療に より得られた成績から今回の成績を差し引けば, 薬物投与の効果が浮き彫りにされ，その大小よ り薬物の有効性の比較が可能である.

我々は，今日までに今回と同様の方法を用い て咽喉頭異常感症の各種薬剤による治療効果を 判定してきた。つまり，薬物投与前の咽喉頭異 常感の強さを一律 10 点とし, 異常感が消失した 状態を 0 点とした場合, 薬物投与後の評価時点 でそれが何点になったかを，患者自身に評価さ せ，それを解析資料としてきた。この方法で評 価された薬物治療成績が今回の成績よりも確か に優れていれば，その薬剤は咽喉頭異常感症に 対して確かに有効であるといえる。

\section{まとめ}

咽喉頭異常感症患者 100 名を投薬を行うこと なく 3 週間治療し, 治療開始前の異常感の強さ を一律 $\lceil 10 」 と し$, 異常感の消失した状態を「0」 とした場合, それ(以下「咽喉頭異常感スコアー」) が $1,2,3$ 週目にはどの様に推移していくかを 観察し, 以下の成績を得た。

1 . 咽喉頭異常感スコアーの平均士標準偏差 は, $1,2,3$ 週目で7. $1 \pm 3.1,6.5 \pm 3.4,6.2 \pm$ 3.8であった。各週に拈けるスコアー 5 以下 $(50$ $\%$ 以上症状が軽減, 我々の判定基準で広義の有
効)の例の比率は，36\%，44\%，45\%であり， 完全に症状が消失した例のそれらはそれぞれ 4 \%，4\%，8\%であった。

2. 無投薬治療は以下のような例に比較的奏 功することが示唆された。

(1)50歳以上，(2)職業を持っていない，(3)合併 症を有している，(4)既に薬物に上る本症の治療 を受けたことがあり，乙かも，それが効果的で あった，(5)咽喉頭異常感を癌の症状とは考劣て いない，6発症後 6 力月以内に本治療を開始し た，7咽喉頭異常感を感じる部位は輪状軟骨よ りも高い位置にある，8異常感は気道あるいは 消化管を何かが締め付けてくる感じである，

(9) コーネル・メディカル・インデックス健康調 査やモーズレイ性格検査で著しい神経症的傾向 がない。

この成績は, 咽喉頭異常感をある程度軽減さ せる目的で無投薬治療を行うことは意義がある が，それを完全に治瘉させようとした場合，無 投薬治療の効果は十分ではなく，咽喉頭異常感 症の第一選択とはならないことを示している.

見方を変えれば，この成績は各種薬物の咽喉 頭異常感に対する効果を, 今回と同様の方法で 評価した際の参考成績となり，薬剤自体の効果 を評価するらえで有用である。

\section{参考文献}

1）山際幹和, 福生治城, 坂倉康夫, 他 : 偽薬とし て用いた安中散による咽喉頭異常感症例の治療 成績. 耳鼻臨床 $76: 3041 \sim 3049,1983$.

2) 山際幹和, 坂倉康夫, 久保将彦, 他: 咽喉頭異 常感に対する Alprazolam の効果 一二重盲検 法に上る臨床的検討一. 耳鼻臨床 $83: 1285$ 1297, 1990.

3) 山際幹和, 久保将彦, 坂倉康夫 : 咽喉頭異常感 に対するインプレトール注射の効果. 日耳鼻 $92: 2023 \sim 2028,1989$.

4) 山際幹和, 坂倉康夫, 原田輝彦, 他: 治療薬剤 之咽喉頭異常感の消失率. 耳鼻臨床 $85: 957$ 961, 1992.

5）金久卓也, 深町 建: コーネル・メディカル・ インデックス. 三京房, 京都, 1980. 
6）MPI 研究会：新・性格検査法 一モーズレイ性 格検査一。誠信書房, 東京, 1981 .

7）山際幹和, 久保将彦, 原田輝彦, 他 : 咽喉頭異 常感に対する咽喉頭粘膜表面麻酔効果. 日耳鼻 $91: 348 \sim 355,1988$.

8）山際幹和, 雨㿼 亮, 坂倉康夫 : 耳鼻咽喉科入 院患者におけるのどがつまる感じの有無と心理 ・性格検査成績.日耳鼻 $92 ： 2017 \sim 2022,1989$.
9) 山際幹和, 福生治城, 西岡博之, 他: Sulpiride による咽喉頭異常感症の治療成績. 耳鼻臨床 $78:$ 1663 1673, 1985.

$\left.\begin{array}{l}\text { 原稿受付 : 平成 } 3 \text { 年 } 11 \text { 月 } 25 \text { 日 } \\ \text { 原稿採択 : 平成 } 3 \text { 年 } 12 \text { 月 } 11 \text { 日 } \\ \text { 別刷請求先 : 山際幹和 } \\ \text { 产 } 514 \text { 津市江戸橋2-174 } \\ \text { 三重大学医学部耳鼻咽喉科学教室 }\end{array}\right)$

